OPEN ACCESS ISSN 25482254 (online) ISSN 20893833 (print)

Edited by:

Enik Setiyawati

Reviewed by:

Deni Adi Putra

${ }^{*}$ Correspondence:

Natalia Peni

nataliapeni27@gmail.com

Received: 9 Juli 2020 Accepted: 10 Agustus 2020

Published: 17 Agustus 2020

Citation:

Peni N, Carvallo L and Priska $M$ (2020) Problem Solving Learning

Model By Integrating ARCS Motivation Strategies On Acid-Base

Subjects.

PEDAGOGIA; Jurnal Pendidikan.

9:2.

doi: 10.21070/pedagogia.v9i2.641

\section{Problem Solving Learning Model By Integrating ARCS Motivation Strategies On Acid-Base Subjects}

\section{Model Pembelajaran Problem Solving Dengan Mengintegrasikan Strategi Motivasi ARCS Pada Materi Pokok Asam Basa}

\author{
Natalia Peni*, Ludovicus Carvallo, Melania Priska \\ Program Studi Pendidikan Matematika, Universitas Flores, Indonesia
}

This study aims to produce a problem solving model of chemistry learning tools by integrating the ARCS strategy so that it is feasible to use it to improve student learning outcomes of the Biology Education Study Program at the University of Flores. The development of the device used the 3-D model which was tested on semester 2 students of the Biology Education Study Program for the 2019/2020 Academic Year. The research design used was one group pretest-posttest. The data collection technique used research instruments, namely the validity of the learning tools, the implementation of the lesson plans, student responses, and student learning outcomes. Student learning outcomes data were analyzed using the analysis prerequisite test, which consists of the normality test, homogeneity test, and t-test. The results showed that the device developed was categorized as valid. This is evidenced by the significance value tcount $<$ ttable, which is $0.000<0.05$. Thus the learning tools developed are valid, practical, effective and can improve student learning outcomes on acid-base subject matter.

Keywords: Problem Solving, ARCS Strategy, Acid-Base

Penelitian ini bertujuan menghasilkan perangkat pembelajaran kimia model problem solving dengan mengintegrasikan strategi ARCS sehingga layak digunakan untuk meningkatkan hasil belajar mahasiswa Program Studi Pendidikan Biologi Universitas Flores. Pengembangan perangkat menggunakan model 3-D yang diujicobakan pada mahasiswa semester 2 Program Studi Pendidikan Biologi Tahun Akademik 2019/2020. Desain penelitian yang digunakan, yakni one grup pretest-posttest. Teknik pengumpulan data menggunakan instrumen penelitian, yakni berupa validitas perangkat pembelajaran, keterlaksanaan rencana pembelajaran, respon mahasiswa, dan hasil belajar mahasiswa. Data hasil belajar mahasiswa dianalisis dengan menggunakan uji prasyarat analisis, yang terdiri dari uji normalitas, uji homogenitas, dan uji-t. Hasil penelitian menunjukkan bahwa perangkat yang dikembangkan berkategori valid. Hal ini dibuktikan dengan nilai signifikansi $t_{\text {hitung }}<t_{\text {tabel }}$, yakni 0,000<0,05. Dengan demikian perangkat pembelajaran yang dikembangkan valid, praktis, efektif dan dapat meningkatkan hasil belajar mahasiswa pada materi pokok asam basa. 


\section{PENDAHULUAN}

Dosen merupakan kunci keberhasilan pendidikan dan pengajaran. Dosen dalam melaksanakan pembelajaran di kelas harus dapat menempatkan aktivitas nyata anak dengan berbagai objek yang dipelajarinya. Mahasiswa didorong untuk melakukan penelusuran masalah, mencari berbagai penjelasan mengenai fenomena yang mereka alami atau temui. Mengembangkan kemampuan motoriknya dan melatih kemampuan bernalar untuk memecahkan masalah dengan melakukan berbagai eksperimen yang relevan. Kenyataan di lapangan, Dosen dalam menyampaikan materi pelajaran cenderung menggunakan model pembelajaran yang kurang tepat. Mahasiswa hanya mempelajari kimia dengan menghafal konsep dan teori. Dalam pembelajaran kimia mahasiswa kurang mengaplikasikan teori yang dipelajari kedalam dunia nyata. Hal ini menyebabkan hasil belajar mahasiswa Program Studi Pendidikan Biologi Universitas Flores rendah. Salah satu penyebab rendahnya hasil belajar kimia adalah sistem pembelajaran yang lebih berorientasi pada isi materi dan tidak dihubungkan dengan fenomena dalam kehidupan sehari-hari Kuswardi et al. (2011). Mahasiswa tidak dilatihkan menemukan konsep/prinsip/solusi dari permasalahan yang diajukan dalam pembelajaran Annisa (2010). Jika kondisi ini dibiarkan maka kemampuan mahasiswa pada mata kuliah kimia akan tetap rendah.

Oleh karena itu, mahasiswa dituntut memiliki motivasi untuk memacu semangat belajar, maka diperlukan strategi motivasi ARCS. Strategi motivasi ARCS terdiri dari empat komponen yang diterapkan dalam proses pembelajaran, yakni mengamati aktifitas mahasiswa (attention), menghubungkan materi dengan masalah dalam kehidupan nyata (relevance), menumbuhkan keyakinan dan rasa percaya diri (confidence), serta memberikan penghargaan atas prestasi yang diperoleh oleh mahasiswa (satisfaction) Stefany et al. (2014). Dalam proses pembelajaran jika keempat komponen ARCS tersebut dimiliki oleh mahasiswa, maka secara psikologi mahasiswa siap mengikuti pembelajaran. Mahasiswa termotivasi mengikuti pembelajaran di kelas apabila materi yang diajarkan bersumber dari masalah-masalah sederhana yang dialami. Hal ini sesuai dengan karakteristik model pembelajaran problem solving.

Pada model problem solving, mahasiswa dilatih mulai dari menemukan masalah sampai menarik kesimpulan Amanda et al. (2018). Pembelajaran dengan problem solving dimulai dengan masalah yang terbuka (open-ended) dalam suatu situasi kontekstual yang mengarah pada prosedur penyelesaian yang terstruktur dengan baik. Dimana Mahasiswa hendaknya memiliki pengetahuan dan pengalaman yang berkaitan dengan masalah, mereka hendaknya menyusun dan mencoba prosedur penyelesaian, hingga merefleksikan dan menjelaskan pengalaman memecahkan masalah Putra and Hasyim (2014); Khairani and Safitri (2018). Materi asam basa merupakan kajian dalam ilmu kimia yang kompleks yang didalamnya terdapat pengetahuan konseptual dan prosedural. Model pembelajaran problem solving merupakan bagian dari pembelajaran dengan penemuan, dimana mahasiswa didorong terlibat secara aktif untuk belajar dengan konsep-konsep dan prinsip-prinsip ilmiah Jauhar (2017). Pada pembelajaran model problem solving dengan mengintegrasikan strategi motivasi ARCS di kelas, pengetahuan awal mahasiswa dikaitkan dengan kehidupan nyata yang berhubungan dengan kehidupan mahasiswa baik berupa pengalaman sekarang atau yang telah dimiliki, maupun yang berhubungan dengan kebutuhan karir sekarang atau yang akan datang Wijayanti et al. (2014) . Mahasiswa akan terdorong mempelajari sesuatu kalau apa yang akan dipelajari ada relevansinya dengan kehidupan mahasiswa, sehingga pembelajaran menjadi lebih optimal.

Berdasarkan angket pra penelitian pada mahasiswa Program Studi Pendidikan Biologi Semester II Fakultas Keguruan dan Ilmu Pendidikan Universitas Flores dan hasil wawancara dengan Dosen mata pelajaran kimia menunjukkan bahwa materi asam basa termasuk salah satu materi dianggap sulit oleh mahasiswa karena materi ini penuh dengan hitungan sehingga jika mahasiswa tidak memiliki konsep asam basa yang kuat maka konsep pengetahuan yang dimiliki akan rendah. Oleh karena itu kemampu kognitif harus diimbani dengan kemampuan psikomotori Sastradewi et al. (2015). Sebanyak 40,62\% menyatakan tidak menyukai materi asam basa karena kurang memahami materi tersebut. Sebagai akibatnya banyak mahasiswa yang 
harus mengikuti pembelajaran remidial untuk mencapai ketuntasan belajar.Salah satu solusi yang dapat dilakukan untuk meningkatkan hasil belajar mahasiswa Program Studi Pendidikan Biologi Fakultas Keguruan dan Ilmu Pendidikan Universitas Flores pada mata kuliah kimia adalah merencanakan dan melaksanakan pembelajaran kimia model problem solving dengan mengintegrasikan strategi motivasi ARCS Fajria et al. (2018) .

\section{METODE}

Jenis Penelitian ini adalah penelitian pengembangan. Pengembangan perangkat penelitian ini mengacu pada model pengembangan 3-D alur penelitian ini dilaksanakan sampai pada tahap pengembangan. Perangkat yang dikembangkan adalah RPS, LKM dan THB. Sampel dalam penelitian ini adalah mahasiswa Program Studi Pendidikan Biologi semester 2, Fakultas Keguruan dan Ilmu Pendidikan Universitas Flores. Waktu penelitian, yakni bulan Mei - Juli 2020. Desain penelitian ini menggunakan rancangan One Group Pretest-Posttest Design. Pola umum rancangan tersebut dapat dinyatakan sebagai berikut, yakni:

\section{$\mathbf{O}_{1} \mathbf{X ~ O}_{2}$}

Keterangan:

$\mathrm{O}_{1}=$ Pengujian awal (pre-test) sebelum pemberian perlakuan

$\mathrm{O}_{2}=$ Pengujian akhir (post-test) sesudah pemberian perlakuan

$\mathrm{X}=$ Perlakuan melalui pembelajaran yang mengintegrasikan strategi motivasi ARCS dalam model pembelajaran problem solving.

Teknik pengumpulan data dalam penelitian ini menggunakan instrumen penelitian, yakni berupa validitas perangkat pembelajaran, keterlaksanaan rencana pembelajaran, respon mahasiswa, dan hasil belajar mahasiswa. Data hasil belajar mahasiswa dianalisis dengan menggunakan uji prasyarat analisis, yang terdiri dari uji normalitas, uji homogenitas, dan uji-t.

\section{HASIL DAN PEMBAHASAN}

\section{Deskripsi Pengembangan Perangkat Pembelajaran}

Hasil pengembangan perangkat model pembelajaran berdasarkan masalah dengan mengintegrasikan strategi ARCS dengan mengadaptasi model pengembangan four D (4D) menjadi langkah pengembangan three $D$ (34) dapat digambarkan sebagai berikut: Pada tahap define (pendefinisian) telah dilakukan hal-hal, yakni : 1) Analisis pendahuluan. Dalam kurikulum program studi pendidikan biologi pada mata kuliah kimia terdapat materi asam basa dengan capaian pembelajaran di mana mahasiswa dapat memahami dan menerapkan konsep asam basa. Dari capaian tersebut kemudian dilakukan observasi terhadap aktivitas belajar dan hasil belajar mahasiswa pada materi asam basa yang berisi konsep, hukum dan hitungan. Hasilnya bahwa aktivitas belajar mahasiswa masih terbatas pada mendengar setiap penjelasan dan aktivitas dosen. Untuk itu diberikan solusi berupa perangkat pembelajaran yang membantu mahasiswa belajar secara mandiri dan terstruktur. 2) Analisis mahasiswa. Pada mahasiswa semester 2 program studi pendidikan biologi kemampuan mahasiswa masih sangat rendah sehingga harus ditingkatkan. Untuk meningkatkan kemampuan mahasiswa maka dikembangkan Rencana Pembeljaran Semester dan Lembar Kerja Mahasiswa (LKM) model pembelajaran problem solving dengan mengintegrasikan strategi motivasi ARCS, agar mahasiswa memahami konsep asam basa. 3) Analisis materi. Materi asam basa pada mata kuliah kimia cukup sulit, dengan demikian mahasiswa harus memiliki kemampuan pengetahuan, konseptual, prosedural, dan metakognitif. Materi asam basa dapat dipahami jika pengetahuan yang berkaitan dengan materi sebelumnya dikuasai dengan baik. Oleh karena itu, format RPS dan LKM yang didesain berlatar belakang keempat aspek kemampuan tersebut. Materi yang disajikan dalam RPS dan LKM meliputi konsep asam basa, indikator asam basa, dan pehitungan asam basa. Ketiga materi saling berkaitan, sehingga mahasiswa dapat dengan mudah menganalisis keterkaitan antara materi Kristanti and Julia (2017); Sari et al. (2017).

Pada tahap design (perencanaan) untuk memenuhi kebutuhan belajar mahasiswa maka format RPS dan LKM yang dipilih dan dirancang harus berisi tujuan pembelajaran, fenomena, 
rumusan masalah, hipotesis, identifikasi variabel, definisi operasional variabel, alat dan bahan, langkah-langkah pengerjaan, data pengamatan, analisis dan kesimpulan. Selanjutnya dilakukan penyusunan desain RPS, LKM, dan THB. Desain RPS, dan LKM di susun berdasarkan model problem solving dengan mengintergasrrikan strategi motivasi ARCS menggunakan bahasa indonesia yang baik dan benar Adamura and Masfingatin (2015). Pada tahap develop (Pengembangan) perangkat pembelajaran yang dihasilkan kemudian divalidasi oleh tim ahli dan di uji coba pada kelas kontrol Ahmad and Asmaidah (2018). Hasil validasi perangkat pembelajaran tertera padaTabel 1 .

[Table 1 about here.]

Dari Tabel 1 terlihat bahwa perangkat pembelajaran yang dikembangkan berkategori valid. Hal ini menunjukkan perangkat pembelajaran dengan model pembelajaran problem solving yang mengintegrasikan strategi ARCS layak digunakan dalam pembelajaran pada materi pokok asam basa Hera et al. (2014). Hasil validasi yang valid menyatakan RPS yang dikembangkan telah memenuhi kriteria Kurikulum Kualifikasi Nasional Indonesia (KKNI) 2015 yang mencakupi: 1) Nama program studi, nama, kode, dan rumpun mata kuliah, bobot (sks), semester, tanggal penyusunan; 2) Capaian pembelajaran lulusan program studi; 3) Capaian pembelajaran mata kuliah; 4) Deskripsi mata kuliah; 5) Bahan kajian/materi pembelajaran (pokok bahasan); 5) Pustaka; 6) Media Pembelajaran; 7) Mata kuliah prasyarat; dan 8) Acara pembelajaran Mardikaningtyas et al. (2016). Hasil validasi LKM dengan kategori valid seperti pada Tabel 1 , didasarkan pada karakteristik problem solving dan strategi ARCS untuk meningkatkan hasil belajar mahasiswa. LKM yang dikembangkan memuat rangkaian aktivitas mahasiswa selama proses pembelajaran berdasarkan langkah-langkah pembelajaran problem solving yang mengintegrasikan strategi ARCS. LKM tersebut praktis digunakan oleh dosen dan mahasiswa pada proses pembelajaran Mardikaningtyas et al. (2016). Pada hasil validasi THB, dikategorikan valid karena THB yang dikembangkan mencerminkan relevansi indikator setiap butir soal mudah untuk dipahami, sehingga waktu pengerjaannya sesuai alokasi waktu yang ditentukan. Selain itu, THB yang dikembangkan juga memenuhi aspek kejelasan petunjuk pengerjaan soal, kejelasan pedoman penskoran, objektifitas pemberian skor, dan kepraktisan Qalbi et al. (2019).

\section{Keterlaksanaan}

Pembelajaran di kelas diharapkan sesuai dengan tujuan pembelajaran. Pembelajaran pada dasarnya merupakan proses interaksi manusia. Interaksi antara mahasiswa dengan dosen terjadi saat pelaksanaan pembelajaran. Pembelajaran tersebut diharapkan sesuai dengan tujuan kegiatan belajar yang telah disesuaikan dengan RPS yang dikembangkan Sitepu and Lestari (2018). Aspek yang diamati selama proses pembelajaran meliputi dua hal, yaitu pengamatan kegiatan belajar mengajar dan suasana kelas. Untuk mengetahui interaksi selama kegiatan belajar mengajar di kelas diperlukan pengamatan dengan menggunakan instrumen keterlaksanaan pembelajaran model problem solving dengan strategi ARCS. Hasil pelaksanaan keterlaksanaan pembelajaran secara ringkas disajikan pada Tabel 2 .

[Table 2 about here.]

Berdasarkan Tabel 2 , hasil keterlaksanaan pembelajaran yang diberikan oleh dua orang pengamat secara keseluruhan berkategori baik. Hasil yang dicapai ini menunjukkan bahwa langkahlangkah pembelajaran yang dilakukan oleh dosen sesuai dengan langkah-langkah pembelajaran model pembelajaran problem solving dengan strategi ARCS yang dikembangkan. Adapun aspek yang diamati meliputi pendahuluan, kegiatan inti, penutup, dan suasana kelas. Pada aspek pendahuluan, dosen memberikan motivasi dan apersepsi untuk memusatkan perhatian mahasiswa terhadap materi yang akan dipelajari. Pada kegiatan inti, materi yang diberikan oleh dosen, didiskusikan bersama. Pada aspek penutup, materi yang telah didiskusikan kemudian dievaluasi dengan memberikan soal untuk mengetahui tercapai tidaknya tujuan pembelajaran yang telah direncanakan pada RPS. Hasil pengamatan suasana kelas berkategori baik karena pada saat proses diskusi kelas, mahasiswa sangat antusias dalam melontarkan pertanyaan maupun dalam memberikan tanggapan. Selain itu juga, dosen membantu mahasiswa menjadi fasilitator pada saat praktikum dan dalam kegiatan diskusi. 


\section{Respon Mahasiswa}

Respon mahasiswa terhadap pembelajaran dengan model pembelajaran problem solving yang mengintegrasikan strategi ACRS dapat dilihat pada Tabel 3 .

[Table 3 about here.]

Persentase respons mahasiswa dianalisa menggunakan kategori 81\% - 100\%: sangat kuat, $61 \%$ 80\%: kuat $41 \%$ - 60\% : cukup, $21 \%$ - 40\%: Lemah, dan 0\% - 20\%: Sangat lemah Putra and Hasyim (2014). Dari Tabel 3 diketahui bahwa pada umumnya respon mahasiswa terhadap semua aspek dalam model pembelajaran problem solving dengan mengintegrasikan strategi ARCS berkategori respon kuat hingga sangat kuat. Namun, ada satu aspek yang berkategori cukup. Hal ini menunjukkan bahwa model pembelajaran problem solving dengan mengintegrasikan strategi ARCS pada materi pokok asam basa mendapat respon positif dari mahasiswa. Dengan menerapkan model pembelajaran ini, mahasiswa memiliki kemampuan berkomunikasi yang tinggi karena pada saat diskusi cara berpikir mahasiswa dilatih untuk menemukan konsep untuk menuangkan ide dan gagasan Ariyawati et al. (2017).

\section{Hasil Belajar Mahasiswa}

Data hasil belajar mahasiswa menerapkan model pembelajaran problem solving dengan mengintegrasikan strategi ARCS dianalisis menggunakan uji normalitas, uji homogenitas, dan uji hipotesis (uji-t).

\section{Uji Normalitas}

Uji normalitas dilakukan untuk mengetahui apakah data hasil belajar mahasiswa berdistribusi normal atau tidak. Adapun uji normalitas pada analisis data menggunakan KolmogorovSmirnov dengan hasil signifikan $>0,05$, baik pada kelas eksperimen dan kontrol. Berdasarkan uji normalitas menggunakan SPSS versi 21.0, hasil belajar kelas eksperimen dan kontrol disajikan pada Tabel 4 .

\section{[Table 4 about here.]}

Data pada Tabel 4 menunjukkan bahwa sebaran data hasil belajar mahasiswa, baik pada kelas eksperimen dan kontrol berdistribusi normal. Hal tersebut dinyatakan dari nilai signifikan yang diperoleh, yakni $\alpha>0,05$, sehingga penggunaan model pembelajaran problem solving dengan mengintegrasikan strategi ARCS pada kelas eksperimen dan kontrol dapat meningkatkan hasil belajar kimia pada materi pokok asam basa.

Uji homogenitas digunakan sebagai syarat dalam analisis independen samplet-tes $t$. Data hasil analisis uji homogenitas hasil belajar mahasiswa untuk mengetahui sama tidaknya variansi distribusi kelas eksperimen dan kontrol disajikan pada Tabel 5 .

[Table 5 about here.]

Berdasarkan Tabel 5 dapat diketahui bahwa nilai signifikansi $>0,05$, yaitu 0,332. Hasil tersebut menunjukkan bahwa hasil belajar mahasiswa memiliki varians yang sama atau homogen Hartiningrum (2017) . Untuk menjawab hipotesis pada penelitian ini mengenai adakah pengaruh pengembangan perangkat pembelajaran kimia dengan mengintegrasikan strategi motivasi ARCS dalam model pembelajaran problem solving pada materi pokok asam basa untuk meningkatkan hasil belajar mahasiswa, peneliti menggunakan uji-t. Kaidah pengujian signifikansi uji-t adalah: Jika $\mathrm{t}_{\text {hitung }}<\mathrm{t}_{\text {tabel }}$, maka $\mathrm{H}_{a}$ diterima; dan Jika $\mathrm{t}_{\text {hitung }}>\mathrm{t}_{\text {tabel }}$, maka $\mathrm{H}_{a}$ ditolak. Uji-t hasil belajar mahasiswa dianalisis menggunakan uji Paired Sample T-Test. Hasil uji disajikan pada Tabel 6 .

[Table 6 about here.]

Berdasarkan Tabel 6 dapat dilihat output pair 1 diperoleh nilai signifikan sebesar 0,000 $<0,05$, maka dapat disimpulkan bahwa ada perbedaan rata-rata hasil belajar mahasiswa untuk pre-test kelas ekperimen dengan post-test kelas eksperimen. Pada output pair 2 diperoleh nilai signifikan 
sebesar $0,000<0,05$, maka dapat disimpulkan ada perbedaan rata-rata hasil belajar mahasiswa untuk pre-test kelas kontrol dengan post-test kelas kontrol model pembelajaran problem solving dengan mengintegrasikan strategi ARCS pada materi pokok asam basa. Dengan demikian perangkat pembelajaran yang dikembangkan valid, efektif, praktis dan dapat meningkatkan hasil belajar mahasiswa pada materi asam basa Yulianti et al. (2019) .

\section{KESIMPULAN}

Perangkat Pembelajaran model problem solving dengan mengintegrasikan strategi ARCS pada materi pokok asam basa yang dikembangkan valid, efektif, praktis dan dapat meningkatkan hasil belajar mahasiswa program studi pendidikan biologi.

\section{UCAPAN TERIMA KASIH}

Peneliti menyampaikan terima kasih kepada Yayasan Perguruan Tinggi Flores (Yapertif) Universitas Flores yang telah memberikan bantuan dana penelitian dosen Hibah Yapertif tahun anggaran 2020, sehingga penelitian ini dapat terlaksana dengan baik.

\section{REFERENCES}

Adamura, F. and Masfingatin, T. (2015). PENGEMBANGAN PERANGKAT PEMBELAJARAN BERDASARKAN MASALAH MATERI GEOMETRI NON EUCLIDES UNTUK MELATIHKAN BERPIKIR KRITIS DAN KREATIF. Jurnal Edukasi Matematika dan Sains 3, 14-14. doi: 10.25273/jems.v3i1.242.

Adiani, F., Rudibyani, R. B., and Efkar, T. (2018). Pengembangan LKS Berbasis Problem Solving untuk Meningkatkan Keterampilan Berpikir Kreatif Materi Asam Basa. Jurnal Pendidikan dan Pembelajaran Kimia 7, 91-103.

Ahmad, M. and Asmaidah, S. (2018). PENGEMBAN GAN PERANGKAT PEMBELAJARAN MATEMATIKA REALISTIK UNTUK MEMBELAJARKAN KEMAMPUAN PEMECAHAN MASALAH MATEMATIKA SISWA SMP. Mosharafa: Jurnal Pendidikan Matematika 6, 373-384. doi: 10.31980/mosharafa.v6i3.326.

Amanda, S., Muharrami, L. K., Rosidi, I., and Ahied, M (2018). Peningkatan Kemampuan Berpikir Kritis pada Pembelajaran IPA menggunakan Model Pembelajaran Berbasis Masalah yang Berbasis SETS. Journal of Natural Science Research 1, 57-64.

Annisa, D. (2010). Penerapan Strategi Motivasi ARCS dalam Model Pengajaran Langsung untuk Meningkatkan Pemahaman Konsep Siswa pada Pokok Bahasan Listrik Dinamis di SMA. Jurnal Dinamkia Sains 3, 30-39.

Ariyawati, P. A. M., Waluyo, J., and Prihatin, J. (2017). Analisis Respon Siswa terhadap Model Pairs, Investigation and Communication (PIC) dalam Pembelajaran IPA. Jurnal Pembelajaran dan Pendidikan Sains 2, 9-15.

Fajria, F., Rahmatan, H., and Halim, A. (2018). DAMPAK MODEL PEMBELAJARAN PROBLEM SOLVING TERHADAP MOTIVASI DAN HASIL BELAJAR PESERTA DIDIK DI SMP. Jurnal Pendidikan Sains Indonesia 5, 8794. doi: 10.24815/jpsi.v5i2.9822.

Hartiningrum, E. S. N. (2017). Pengaruh Model Pembelajaran Kooperatif Teknik Kancing Gemerincing terhadap Hasil Belajar Matematika Siswa Kelas XI SMK Telekomunikasi Peterongan Jombang. Suska Journal of Mathematics Education 3, 1-1. doi: 10.24014/sjme.v3i1.3220.

Hasyim, F. (2019). Analisis Respon Siswa terhadap Penggunaan KIT Kalorimeter dalam Pembelajaran IPA Pokok Bahasan Kalor. Berkala Ilmiah Pendidikan Fisika 7, 11-18.

Hera, R., Khairil, and Hasanuddin (2014). Pengembangan Handout Pembelajaran Embriologi Berbasis Kon- tekstual pada Perkuliahan Perkembangan Hewan untuk Meningkatkan Pemahaman Konsep Mahasiswa di Universitas Muhammadiyah Banda Aceh. Jurnal Edubio Tropika 2, 187-250.

Jauhar, S. (2017). Penerapan Model Pembelajaran Problem Solving Dalam Meningkatkan Hasil Belajar IPS Siswa SD. JIKAP PGSD: Jurnal Ilmiah Ilmu Kependidikan 2, 141-141. doi: $10.26858 /$ jkp.v1i2.5285.

Khairani, I. and Safitri, R. (2018). PENERAPAN METODE PEMBELAJARAN PROBLEM SOLVING UNTUK MENINGKATKAN HASIL BELAJAR PESERTA DIDIK PADA MATERI USAHA DAN ENERGI DI MAN RUKOH BANDA ACEH. Jurnal Pendidikan Sains Indonesia 5, 32-41. doi: 10.24815/jpsi.v5i2.9814.

Kristanti, D. and Julia, S. (2017). Pengembangan Perangkat Pembelajaran Matematika Model 4-D untuk Kelas Inklusi sebagai Upaya Meningkatkan Minat Belajar Siswa. Jurnal MAJU 4, 38-50.

Kuswardi, Y., Kurniawati, I., and Sutopo, S. (2011). EFEKTIFITAS MODEL PEMBELAJARAN DIRRECT INSTRUCTION DENGAN STRATEGI MOTIVASI ARCS PADA MATERI GRAPH. Journal of Mathematics and Mathematics Education 1, 1-9. doi: 10.20961/jmme.v1i1.9916.

Mardikaningtyas, D. A., Ibrohim, and Suarsini, E. (2016). Pengembangan Pembelajaran Pencemaran Lingkungan Berbasis Penelitian Fitoremediasi untuk Menunjang Keterampilan Ilmiah, Sikap Peduli Lingkungan dan Motivasi Mahasiswa pada Matakuliah DasarDasar Ilmu Lingkungan. Jurnal Pendidikan: Teori, Penelitian, dan Pengembangan 1, 499-506. doi: http://dx.doi.org/10.17977/jp.vli3.6179.

Putra, F. K. A. and Hasyim, B. A. (2014). Penerapan Model Pembelajaran Problem Solving untuk Meningkatkan Hasil Belajar Siswa Kelas XII TKR 1 pada Mata Pelajaran Sistem Pengapian Konvensional di SMK Negeri 1 Madiun. Jurnal Pendidikan Teknik Mesin 2, 1-8.

Qalbi, N. A., Zainuddin, Z., and Miriam, S. (2019). Validitas dan Kepraktisan Perangkat Pembelajaran dengan Metode Problem Solving melalui Model Pengajaran Langsung pada Materi Usaha Energi. Jurnal Ilmiah Pendidikan Fisika 3, 125-125. doi: 10.20527/jipf.v3i3.1041.

Sari, W., Jufrida, and Pathoni, H. (2017). Pengembangan Modul Elektronika Berbasis 3D Pageflip Professional pada Materi Konsep Dasar Fisika Inti dan Struktur Inti Mata Kuliah Fisika Atom dan Inti. Jurnal EduFisika 2, 38-50. doi: https://doi.org/10.22437/edufisika.v2i01.4041. 
Sastradewi, P. F., Sadia, I. W., and Karyasa, N. I. W. (2015). Pengembangan Perangkat Pembelajaran Kimia yang Menerapkan Model Problem Based Learning untuk Meningkatkan Pemahaman Konsep Siswa. E-Journal Program Pascasarjana Universitas Pendidikan Ganesha 5, 112.

Sitepu, B. P. and Lestari, I. (2018). PELAKSANAAN RENCANA PEMBELAJARAN SEMESTER DALAM PROSES PEMBELAJARAN DI PERGURUAN TINGGI. Perspektif Ilmu Pendidikan 32, 41-49. doi: 10.21009/pip.321.6.

Stefany, E. M., Candiasa, M., and Warpala, I. W. S. (2014). Pengaruh Strategi ARCS (Attention, Relevance, Confidence, and Satisfaction) terhadap Motivasi dan Hasil Belajar TIK Siswa Kelas VIII di SMP Negeri 4 Negara. Jounal Program Pasca Sarjana Universitas Pendidikan Ganesha 4 1-9.

Wijayanti, N. S., Haryono, and Saputro, A. N. C. (2014) Penerapan Pembelajaran Problem Solving untuk Meningkatkan Kreativitas dan Prestasi Belajar pada Materi Pokok Larutan Penyangga Siswa Kelas XI MIA 3 Semester Genap SMA Batik 2 Surakarta Tahun Pelajaran. Jurnal Pendidikan Kimia (JPK) 4, 132-138.
Yulianti, Y., Murdani, E., and Kusumawati, I. (2019). Pengaruh Penerapan Model Pembelajaran Attention, Relevance, Confidence, Satisfaction (ARCS) terhadap Motivasi Belajar dan Hasil Belajar Siswa pada Materi Kalor di Kelas X. Variabel 2, 24-30. doi: 10.26737/var.v2i1.1029.

Conflict of Interest Statement: The authors declare that the research was conducted in the absence of any commercial or financial relationships that could be construed as a potential conflict of interest.

Copyright (c) 2020 Peni, Carvallo and Priska. This is an openaccess article distributed under the terms of the Creative Commons Attribution License (CC BY). The use, distribution or reproduction in other forums is permitted, provided the original author(s) and the copyright owner(s) are credited and that the original publication in this journal is cited, in accordance with accepted academic practice. No use, distribution or reproduction is permitted which does not comply with these terms. 


\section{LIST OF TABLES}

Hasil Validasi PerangkatPembelajaran . . . . . . . . . . . . . . . 157

Hasil Pengamatan Keterlaksanaan Pembelajaran . . . . . . . . . . . . . . . 158

Hasil Respon Mahasiswa . . . . . . . . . . . . . . . . . . . . . . . . . . . . . . . . . . . . . . . . . .

Hasil Uji Normalitas . . . . . . . . . . . . . . . . . . . . . . . . . . . . . . . . . . . . . . .

Uji Homogenitas Varian . . . . . . . . . . . . . . . . . 161

Uji Paired Sample T-Test . . . . . . . . . . . . . . . . . . . 162 
TABLE 1 | Hasil Validasi PerangkatPembelajaran

\begin{tabular}{ll}
\hline Jenis Perangkat & Kategori \\
RPS & Valid \\
LKM & Valid \\
THB & Valid \\
\hline
\end{tabular}


TABLE 2 | Hasil Pengamatan Keterlaksanaan Pembelajaran

\begin{tabular}{lll} 
No. & Aspek yang Diamati & Kategori \\
I & Pendahuluan & Baik \\
II & Kegiatan Inti & Baik \\
III & Penutup & Baik \\
IV & Suasana Kelas & Baik \\
\hline
\end{tabular}


TABLE 3 | Hasil Respon Mahasiswa

\begin{tabular}{|c|c|c|c|}
\hline No. & Uraian Pertanyaan & Penilaian/Pendapat & \\
\hline \multirow{4}{*}{1.} & $\begin{array}{l}\text { Bagaimana pendapat kalian terhadap } \\
\text { komponen berikut? }\end{array}$ & $\begin{array}{l}\text { Tertarik } \\
\text { (\%) }\end{array}$ & $\begin{array}{l}\text { Tidak Tertarik } \\
\text { (\%) }\end{array}$ \\
\hline & - a. Materi perkuliahan & 100 & 0 \\
\hline & - b. Tes hasil belajar & 80 & 20 \\
\hline & - c. Suasana pembelajaran di kelas & 95 & 5 \\
\hline & - d. Cara dosen mengajar & 85 & 15 \\
\hline 2. & $\begin{array}{l}\text { Bagaimana tanggapan anda, jika pokok } \\
\text { bahasan selanjutnya menggunakan } \\
\text { model pembelajaran problem solving } \\
\text { dengan strategi ACRS? }\end{array}$ & $\begin{array}{l}\text { Berminat (\%) } \\
83\end{array}$ & $\begin{array}{l}\text { Tidak Berminat } \\
(\%) \\
17\end{array}$ \\
\hline \multirow{6}{*}{3.} & Apakah pendapat kalian tentang? & Baru (\%) & Tidak (\%) \\
\hline & - a. Materi perkuliahan & 90 & 10 \\
\hline & - b. LKM & 95 & 5 \\
\hline & - c. Tes hasil belajar & 83 & 17 \\
\hline & - d. Suasana pembelajaran di kelas & 90 & 10 \\
\hline & - e. Cara dosen mengajar & 80 & 20 \\
\hline 4. & $\begin{array}{l}\text { Apakah anda sudah pernah diajarkan } \\
\text { menggunakan model pembelajaran prob- } \\
\text { lem solving dengan strategi ACRS? }\end{array}$ & $\begin{array}{l}\text { Sudah Pernah (\%) } \\
0\end{array}$ & $\begin{array}{l}\text { Belum Pernah } \\
(\%) \\
100\end{array}$ \\
\hline 5. & $\begin{array}{l}\text { Bagaimana pendapatmu, jika pada } \\
\text { materi selanjutnya diajarkan menggu- } \\
\text { nakan model pembelajaran problem } \\
\text { solving dengan strategi ACRS? }\end{array}$ & $\begin{array}{l}\text { Setuju (\%) } \\
75\end{array}$ & $\begin{array}{l}\text { Tidak Setuju (\%) } \\
25\end{array}$ \\
\hline 6. & $\begin{array}{l}\text { Bagaimana pendapatmu, jika mata kuliah } \\
\text { lain diajarkan menggunakan model pem- } \\
\text { belajaran problem solving dengan strategi } \\
\text { ACRS? }\end{array}$ & $\begin{array}{l}\text { Setuju (\%) } \\
60\end{array}$ & $\begin{array}{l}\text { Tidak Setuju (\%) } \\
40\end{array}$ \\
\hline 7. & $\begin{array}{l}\text { Bagaimana tanggapanmu terhadap } \\
\text { penampilan tulisan, ilustrasi/gambar yang } \\
\text { terdapat dalam LKM dan Tes Hasil Belajar } \\
\text { (THB)? }\end{array}$ & $\begin{array}{l}\text { Tertarik (\%) } \\
85\end{array}$ & $\begin{array}{l}\text { Tidak Tertarik (\%) } \\
15\end{array}$ \\
\hline 8. & $\begin{array}{l}\text { Bagaimana pendapatmu terhadap } \\
\text { bahasa yang digunakan dalam LKM dan } \\
\text { Tes Hasil Belajar (THB) }\end{array}$ & $\begin{array}{l}\text { Tertarik (\%) } \\
80\end{array}$ & $\begin{array}{l}\text { Tidak Tertarik (\%) } \\
20\end{array}$ \\
\hline 9. & $\begin{array}{l}\text { Bagaimana penjelasan dosen pada saat } \\
\text { proses belajar berlangsung? }\end{array}$ & $\begin{array}{l}\text { Jelas (\%) } \\
85\end{array}$ & $\begin{array}{l}\text { Tidak Jelas (\%) } \\
15\end{array}$ \\
\hline 10. & $\begin{array}{l}\text { Bagaimana bimbingan dosen pada saat } \\
\text { anda menemukan konsep melalui eksper- } \\
\text { imen? }\end{array}$ & $\begin{array}{l}\text { Jelas }(\%) \\
85\end{array}$ & $\begin{array}{l}\text { Tidak Jelas (\%) } \\
15\end{array}$ \\
\hline
\end{tabular}


TABLE 4 | Hasil Uji Normalitas

\begin{tabular}{clllllll}
\hline & \multicolumn{3}{l}{$\begin{array}{l}\text { Kolmogorov- } \\
\text { Mahasiswa }\end{array}$} & \multicolumn{5}{c}{ Shapiro-Wilk } \\
& $\begin{array}{l}\text { Smirnova } \\
\text { Statistic }\end{array}$ & df & Sig. & Statistic & df & Sig. \\
&, 112 & 20 &, $200^{*}$ &, 943 & 20 &, 267 \\
Pre-test Kontrol &, 143 & 20 &, $200^{*}$ &, 904 & 20 &, 049 \\
Hasil Post-test Kontrol &, 112 & 20 &, $200^{*}$ &, 943 & 20 &, 267 \\
Belajapre-test Ekperimen &, 171 & 20 &, 128 &, 881 & 20 &, 018 \\
Post-test Eksperimen & & & & & & &
\end{tabular}


TABLE 5 | Uji Homogenitas Varian

Hasil Belajar

Levene Statistic df1 df2 Sig.

1,156

$3 \quad 76 \quad 332$


TABLE 6 | Uji Paired Sample T-Test

\begin{tabular}{|c|c|c|c|c|c|c|c|c|c|}
\hline & & \multicolumn{7}{|c|}{ Paired Differences } & \multirow{3}{*}{$\begin{array}{l}\text { Sig. (2- } \\
\text { tailed) }\end{array}$} \\
\hline & & \multirow[t]{2}{*}{ Mean } & \multirow[t]{2}{*}{$\begin{array}{l}\text { Std. } \\
\text { Deviation }\end{array}$} & \multirow[t]{2}{*}{$\begin{array}{l}\text { Std. } \\
\text { Error } \\
\text { Mean }\end{array}$} & $\begin{array}{l}95 \% \\
\text { Interval } \\
\text { ence }\end{array}$ & $\begin{array}{l}\text { Confidence } \\
\text { of the Differ- }\end{array}$ & $\mathrm{t}$ & df & \\
\hline & & & & & Lower & Upper & & & \\
\hline $\begin{array}{l}\text { Pair } \\
1\end{array}$ & $\begin{array}{l}\text { Pre-test } \\
\text { Eksperimen } \\
\text { - Post-test } \\
\text { Eksperimen }\end{array}$ & $-5,850$ & 3,048 & ,682 & $-7,277$ & $-4,423$ & $-8,582$ & 19 & ,000 \\
\hline $\begin{array}{l}\text { Pair } \\
2\end{array}$ & $\begin{array}{l}\text { Pre-test } \\
\text { Kontrol - } \\
\text { Post-test } \\
\text { Kontrol }\end{array}$ & $-4,450$ & 2,856 & ,639 & $-5,787$ & $-3,113$ & $-6,969$ & 19 & ,000 \\
\hline
\end{tabular}

